\title{
The nursing professional in an Intensive Therapy Unit*
}

\author{
O ser profissional de enfermagem em Unidade de Terapia Intensiva
}

El ser profesional de enfermería en una Unidad de Cuidados Intensivos

\begin{abstract}
Objective: The aim of this study is to gain insight into the meaning of being a nursing professional working in a public Intensive Therapy Unit (ITU). This study addresses aspects related to their way of being and feeling from the perspective of ITU patients care and treatment. Methods: A qualitative research was applied based on a phenomenological background. The guiding question of the study was "what does it mean to you being an ITU nursing professional?" Results: The results show that the lack of human and material resources in the ITU contributes to a feeling of low self-esteem. It pointed out a stressfull work which can lead to problems in the health assistance quality. Conclusion: The stress at work affects psychologically the ITU nursing professionals and it can have negative outcomes in the patients treatment, caused by the isolation and aleniation phenomena.
\end{abstract}

Keywords: Intensive therapy units; Nursing staff, hospital; Caregivers; Nursing, team

\section{RESUMO}

Objetivo: Compreender o significado de ser um profissional de enfermagem atuando em uma Unidade de Terapia Intensiva (UTI), a partir do cuidado prestado. Métodos: Trata-se de uma pesquisa qualitativa, com fundamentação fenomenológica tendo como questão orientadora: “O que significa, para você, ser um profissional de enfermagem trabalhando na UTI??. Resultados: As reflexões desvelaram que a falta de materiais e de profissionais valorizados de enfermagem faz com que se sintam menosprezados e insatisfeitos. Esse ambiente estressante leva à deficiência na qualidade da assistência. O funcionário, ao se distanciar de si mesmo, torna-se isolado do mundo, aliena-se. Conclusão: Conclui-se que ser um profissional de enfermagem em UTI significa enfrentar o desafio de atuar em condições estressantes e sem reconhecimento, porém o trabalho mostra-se, muitas vezes, gratificante.

Descritores: Unidades de terapia intensiva; Recursos humanos de enfermagem no hospital; Cuidadores; Equipe de enfermagem

\section{RESUMEN}

Objetivo: Comprender el significado de ser un profesional de enfermería que trabaja en una Unidad de Cuidados Intensivos (UCI), a partir del cuidado prestado. Métodos: Se trata de una investigación cualitativa, con fundamentación fenomenológica que tuvo como pregunta orientadora: "Qué significa, para Ud., ser un profesional de enfermería que trabaja en la UCI?". Resultados: Las reflexiones develaron que la falta de materiales y de profesionales valorizados de enfermería hace con que se sientan menospreciados e insatisfechos. Ese ambiente estresante lleva a la deficiencia en la calidad de la asistencia. El funcionario, al distanciarse de sí mismo, se torna aislado del mundo, se aliena. Conclusión: El ser un profesional de enfermería en UCI significa enfrentar el desafío de trabajar en condiciones estresantes y sin reconocimiento, no obstante el trabajo se muestra, muchas veces, gratificante.

Descriptores: Unidades de cuidados intensivos; Recursos humanos de enfermería en el hospital; Cuidadores; Equipo de enfermería

\footnotetext{
"Extracted from the Master's degree thesis "The hidden face of the nursing professionals who work in an intensive therapy unit: a phenomenological approach", presented to the Graduate Program of the Nursing Department at the Universidade Federal de São Paulo - UNIFESP - São Paulo, (SP), - Brazil.

${ }^{1}$ Master of Science, Specialist in Intensive Therapy Units; Nursing Supervisor at the Adult ITU of the Hospital Geral Vila Nova Cachoeirinha. São Paulo, (SP), Brazil.

${ }^{2}$ Ph.D., Full Professor at Faculdade de Educação da Pontifícia Universidade Católica de São Paulo PUC-SP-São Paulo, (SP), Brazil.

${ }^{3}$ Ph.D., Full Professor, Administrative Pro-director, Leader of the Núcleo de Ensino Pesquisa e Extensão de Formação e Educação em Saúde - NEPEFES (CNPq-FASM), Pursuing post-doctorate at the Centro de Desenvolvimento do Ensino Superior em Saúde - Universidade Federal de São Paulo/ CEDESSUNIFESP Centro de Desenvolvimento do Ensino Superior em Saúde - Universidade Federal de São Paulo/ CEDESS-UNIFESP São Paulo, (SP), Brazil.
} 


\section{INTRODUCTION}

Despite the efforts of professionals who work in intensive therapy units (ITU), they are regarded as cold settings and many consider them to perform mechanical practices. Such opinion is fruit of the patients reports. This point of view leads them to fear hospitalization in this sector, even though this unit stands out in the hospital setting, either in equipment or professional qualification, which enables greater patient recovery.

The ITU is not only a service with special equipment. One of the primary concerns in it is the assistance provision, by means of interpersonal relationships, which is ensured by verbal and non-verbal communication. This setting is supposed to provide the clients and their families with safety and emotional support, along with guided attitude to improve the existing technological resources ${ }^{(1)}$.

Being hospitalized, especially in an ITU, is something that makes the human being to ponder, even briefly, and is accompanied by afflictions, doubts and fears, mainly of not receiving humanized care.

An ITU, for being a sector in which technology is constantly embedded in the client care with death risk, is considered as a complex unit and the acting professionals in this setting are often perceived as insensitive. They control the assistance, prioritizing the biological aspect, or even the mechanical dimension, due to their skills in dealing with the equipment. Yet, human dimension is the reason and origin of the technological creation and, therefore, these professionals have been warned against the need of rescuing the human aspect in these units. These professionals have been thinking more and more consciously about who the client treated by them is, as well as their specificities in order to provide care that transcends the physical and biological body and what is feasible(2).

The nursing professionals working in an ITU provide care to the hemodynamically unstable individuals Hospitalization makes these patients anxious, with shaken emotions and feelings, as they are living in a strange setting with people not belonging to their milieu. However, they have at their disposal state-of-the-art technology, which is a great ally of the treatment success. For this nursing assistance to have good quality and be humanized, it is necessary an interpersonal professional-client relationship, in which verbal and non-verbal communication and touching are used as care instruments. By using these instruments, these patients' anxiety and fear of the unknown are likely to be decreased.

Nursing is the art and the care science, people care. In order to make it feasible, it is necessary to have an interaction process between those who care and those who are cared; it is necessary information and feelings exchange among people ${ }^{(3)}$.
The act of caring in nursing establishes an extremely close relationship, often intimate, with intense physical contact and filled with sensations and feelings. This direct action over the body of the patient makes the professional or nursing student to be in touch with the client's intimacy ${ }^{(4)}$.

When the actions are developed within ethical values in the occupation and mainly with a touch of humanization, the other professionals and even society will value and recognize this profession as an essential and necessary element for the care.

\section{OBJECTIVE}

This work had the purpose of understanding how nursing professionals feel working in an ITU and learning their way of being and feeling after patient care. In upcoming studies, the theme is likely to be deepened based on an approach founded on the existence analysis.

\section{METHODS}

The phenomenological qualitative research was chosen, in the Situated Phenomenon modality, besides focusing on pre-reflexive phenomena, from what is experienced by the subject (nursing professionals), because it seeks to reveal what is significant and learn these peoples' feelings. There is the likelihood of an empathetic relationship between researcher and researched.

Espósito ${ }^{(5)}$ argues that phenomenology is not concerned with the facts or causality, but seeks to address the world and apprehend it, qualitatively. She is concerned with the phenomenon essence, from the experience, and her investigation attempts to interrogate the thing itself. The phenomenon is understood as something that appears for awareness, as a result of interrogation.

\section{Settings and agents: the questioning region}

The subjects in this research are nursing professionals working in an adult ITU, of a large hospital localized in the São Paulo metropolitan region. The institution was chosen for it was the setting where the questions regarding the phenomena was initiated.

Even risking being qualified as naive researchers, we see the subjects of this research as angels, possessing a special soul, with energy, who were put on the patients' way with the mission of 24-hour care a day. We perceive in each patient a human being who needs care, who should be assisted with a humanizing touch, full of warmth, that is, nursing assistance focused on health maintenance and promotion, as well as disease prevention and its complications. The essence of the nursing professional activity is the humanized care with quality. Thus, we believe that, while these professionals (ANGELS) exist and while 
there is a chance of being one of them, there will be hope and one day we will be able to become a great legion of Angels in white. Therefore, the hospitalized patients will be immune to mechanical care, receiving worthy human being care, that is, humanized care.

We believe that based on these understandings, we will contribute to searching for new care action perspectives in the ITU.

Our purpose was to interview nurses and nursing assistants working in an established ITU.

The invitation to take part in the research was made previously and after employee acceptance, the interviews were scheduled and performed in the unit, with concern not to interfere in the procedure hours and guarantee the subject privacy in the research. The interviews were performed from an open question, having as a guiding question: what does it mean to you being a nursing professional working in an ITU? The dialogs were recorded for posterior analysis.

\section{Procedures}

Before initiating the data collection, the research project was approved by the Committee of Ethics in Research of São Paulo Federal University, with authorization CEP: 0060/05.

All the participants in the research signed the consent form, according to federal resolution n. ${ }^{\circ}$ 196/96, of the National Health Council. The 8 research participants were identified by angel names.

The Interview Phenomenological Analysis and the Study Development

We found that the comprehensive report analysis represented the intersubjectivity moment. A moment for our researchers' thoughts to meet the research participants thoughts, which enabled us to explain the aspects apprehended in the descriptions. After data collection, the data saturation (discourses) occurred when there were 8 discourses.

We initiated each interview reading attempting to familiarize with the total. We performed the discourse reading attempting to find the interviewees' world and approach as much as possible their speeches.

Later, we returned to the discourses more carefully, focusing on the studied thematic, ensuing the emerging of units of meaning. A unit of meanings is, in general, part of a description, whose constituents related to one another, indicating significant moments of discourse. Hence, we were concerned about capturing, not only what is clearly shown, but also having the sensibility to get to perceive the subjects' experiences. The researcher is a meaning attributer

Thus, we extracted and grouped the units of meanings in each discourse, with the purpose of gathering what emerged in common out of this experience. Afterwards, we attempted to find thematic convergences, idiosyncrasies and divergences found in individual discourses in order to group the similar units of meanings. With the convergences coming from the ideographic analysis, we built thematic confluences, which express the general structure essence of the phenomenon that eventually constituted the nomothetics confluences. Sequentially, we performed the comprehensive/interpretative result analysis.

\section{RESULTS}

Thematic confluences: "Expressing the satisfaction and dissatisfaction level out of working in an Intensive Therapy Unit"

The research participants, when answering about the meaning of being a nursing professional working in an ITU, expressed their feelings related to the fact that they worked in an ITU, which are satisfaction and dissatisfaction, inextricable intertwined feelings, reflecting the come and go dialetics of the human existence.

In these employees' daily life, satisfaction emerges clearly, indicating coherence between discourse and practice. These professionals enjoy acting with the client and show nimbleness at their daily work. Such reports can be observed in the following speeches:

"I enjoy working in the ITU a lot because I'm helping these patients who are in need of help, assistance and health control."(Archangel Hakamiah)

"When I started working at the ITU, I liked it a lot because you have the opportunity to grow professionally, to know procedures that are not used in other clinics, mainly being able to communicate with the intubated patient through gestures and signals".(Archangel Daniel)

"Well, I enjoy working at the ITU at night. I can organize myself. But there are some things that hinder the assistance quality, for example, professional stress, but I get happy when the patient is discharged". (Archangel Omael)

These testimonies reveal that the professionals enjoy working in the ITU because in this sector they have the opportunity to grow, acquiring technical-scientific knowledge and creating a type of different care practice, which gives them satisfaction.

The intensive therapy units receive acute patients, and hinges on highly sophisticated equipment and staff with knowledge and experiences that enable these patients treatment. Furthermore, the institutions provide these employees with training and updates, related to the technology use and renovation and ITU care practice. A technological view means to unite scientific knowledge to technique, aiming at providing technological care to 
the patient. The professionals who work in this sector are responsible for the quality of the care given, which makes them feel satisfied and valued.

Contrasting with satisfaction, professional dissatisfaction emerges and is often manifested as frustration, impotence and devaluation feelings. These feelings appear in the discourses when some research subjects are involved in administrative or bureaucratic activities, leading to hindrance in the development of care delivery tasks. Yet, the referred feelings are brought out when they can not perform all the planned activities in their work shift or when the body of employees is reduced, considered insufficient to provide care with quality and humanization. These dissatisfactions can be seen in the following speeches:

"Another thing I feel is that the night shift worker is not valued. This is seen at work. At night, the number of employees is lower than in the day shift, but even so I attempt to provide bumanized care with quality, but I can't'. (Archangel Ariel)

"... most support sectors are closed. That's the reason why there is lack of supplies at night. Then, you feel really anxious; you waste time to solve problems that appear. They make you get far from the patient assistance". (Archangel Rafael)

In these employees' testimonies we see that in the night shift, the number of employees is reduced and that they do not feel valued. There is lack of supplies and equipment. They end up deviating from assistance and providing assistance without quality.

The nursing assistance given to these patients brings countless benefits but is not risk-free. Thus, in these situations, the concern about risk prevention is justified. With the gravity normally shown by patients in critical status hospitalized in the ITU, the high technology used and the complexity of care inherent to the treatment, it is seen in the daily routines of these units that even minor failures throughout care may have harmful consequences to the patients ${ }^{()}$.

The quality and amount of supplies available in the unit are also decisive factors to resume a competent nursing assistance. They can risk both the nursing professionals as the people that they assist.

The quantitative deficit in the body of nursing employees generates activity overload, dissatisfaction at work and increased physical and mental burnout. Consequently, it makes quality assistance unviable, often risking the client's health. This inadequacy may also legally compromise the institution by failures occurred during care.

According to Silva ${ }^{(7)}$, the American Nursing Association conceptualizes quality in nursing care, based on procedures without errors, which assist the patient as appropriately as possible, with ethical principles, aiming at having balance and guaranteeing satisfaction.

\section{Thematic confluences: "Physical alterations experienced by nursing professionals during the shift in the ITU"}

In this second thematic confluence, the physical alterations experienced by the research subjects are analyzed in their shifts and also the repercussions, that is, the formulation of these empirical confluences, namely stress, sleepiness, perception difficulty, anxiety and tiredness.

When the shift is over and the employees return to their homes, the nursing professionals often need to do domestic chores, resume nursing activities in other institutions or even perform other daily activities, which constitute one more stressful factor. Thus, they have difficulties in seeing themselves as human beings, they have difficulties in leisure and in living with family and society.

In this perspective of being in the world, the conflict is visible: wanting a job that favors their professional and human growth and limited world facticity.

The clients often feel pain or want some water, expressing through non-verbal signals such as whispering, facial expression, looks and hand gestures. Most of the time, the professional understands what they want, but answers coldly: "It's not time to administer medication. You cannot drink water. Wait a little. I'll give medicine to another patient and will be right back". Actually, the hospitalized patients in the ITU often wants a little attention, conversation and not pain-killers; for the clients, their lips care is a symbol of attention, respect and even love.

The development of the nursing worker, under the mentioned conditions, is marked, besides time, by a fast paced rhythm, by lack of supplies or equipment and by hurried performance at work, since the hospital is overcrowded and the lack of staff overwhelms the professionals. Thus, questions like stress, sleepiness, perception difficulties, anxiety and tiredness are mentioned by most interviewed people, as the speeches show:

"Sometimes I get stressed because I want to provide good nursing assistance care to this patients, but, unfortunately, sometimes, we bappen to lack supplies in the sector, drugs and suchlike". (Archangel Hakamiah)

"... there are some things that binder the assistance quality, for example, the professional stress. Because during the night, there isn't a suitable number of employees working and this lack of employees hinder the assistance quality. This sometimes leads me to stress.” (Archangel Omael)

Most nursing professionals face, in their routine, 
difficulties to provide assistance to the clients that they have responsibility for. Lack of supplies, work overload and lack of time prevents us from performing our job, which is to provide assistance with quality and humanization. This is an important stress factor at work.

Several authors depict nursing as a stressful occupation due to the responsibility for people's lives and proximity to clients with nearly unbearable suffering, who demand professional dedication, increasing the likelihood of physical and psychological burnout ${ }^{(8)}$.

Maybe, even more serious is the fact that the individual, when concerned about providing assistance within the professional ethical values, reveals the need of thought deviation from the main tasks due to lack of supplies, equipment and staff. This causes a feeling of extreme frustration.

Ferrareze, Ferreira and Carvalho ${ }^{(9)}$ carried out a study, in which they investigated the occurrence of stress in nurses working with critical ITU patients in a university hospital. The authors obtained data that confirm those from specialized literature. More than half of the workers $(66.6 \%)$ who assist critical patients showed signs of physical or psychological suffering characteristic of the stress resistance phase.

The occupational stress occurs when the workers realize their lack of emotional abilities to meet professional demands, which brings suffering, indisposition and feeling of incapacity to face them.

The job conditions are generated from stress factors which take place when there is deterioration in the employee relationship, generating a hostile environment among people, with waste of time in useless arguments. The team members start to work isolated with little cooperation. Furthermore, there is a political approach inadequacy with unhealthy competition. The individual difficulty in adapting to a dynamic setting should be taken into account, involving personal interests and the psychosocial setting ${ }^{(10)}$.

Regarding the repercussion of the night shift for personal life, the first question expressed by the interviewed people was that they take the job stress to their households, impairing their family relationships. Such facts can be observed in the following discourses:

"This tiredness comes from stress. This stress, you end up taking to your private life and you don't have patience and, eventually, you're not patient at home and during the time you're working". (Archangel Ariel)

"The lack of supplies and staff can make us leave the ITU. And to organize it, we depend on other employees, other sectors. The bad point is that sometimes we don't get it". This makes me too tired". (Archangel Omael)

As seen, the overload of tasks, the lack of staff, the bureaucratic activities and the time limitations to perform their tasks are factors that generate conflicts and professional burnout. Indeed, there should be an institutional policy so as to offer worthy working conditions, considering the subjectivity and intersubjectivity of workers and patients. Once again, it becomes a time-consuming factor since there is not in their shifts any time dedicated to qualification. Likewise, they do not realize the job interpenetration in the personal private setting and interpersonal that causes less indisposition flexibility.

Hence, it is necessary to review such situations and mechanisms that restructure the nursing practice in order to provide these professionals with better working conditions and reduction of their deleterious health effects.

The health services require 24-hour a day professionals, especially in nursing. This causes changes in the professionals' biological clock. They need to work at night and sleep during the day in order to meet their sleep and rest needs.

Atkinson ${ }^{(11)}$ states that when people do not sleep properly, they develop tiredness sensations, irritability, depression, stress and lack of control.

Such facts can be observed in the following discourses:

"Working at night I feel stressed. We do feel sleepy and this leads to stress. You show difficulties in perception, in reflex". (Archangel Ariel)

"Until 3 in the morning I'm not sleepy and not tired, but after that, I get sleepy and tired". (Archangel Daniel)

"... working at night I feel stressed because we feel too sleepy. You can't take a rest in the wards. Sometimes I feel hungry during the day and can't sleep." (Archangel Caliel)

The testimonies above demonstrate that the research subjects working at night feel sleepy and tired. This makes them stressed with lack of perception and reflex.

Rutenfranz and Knauth ${ }^{(12)}$ state that, besides the sleep hour change, there is also alteration in the time to eat, which may cause appetite and gastrointestinal disorders, since the gastric juice secretion, required by digestion, practically does not occur late at night. The causes of these health disorders, however, should not be attributed solely to intake irregularities in the night shift. These gastrointestinal alterations may mean manifestations of organic responses to the increase in the professional stress level.

The sleepiness cause is the organism performance reduction at night. It appears to be influenced by a combination of alteration factors in the cicardian rhythmicity and sleep disorders, when the organism reaches a lower alert level around $11 \mathrm{pm}^{(13)}$. 
The night shift workers should be alert to their physiological and psychological health, which may suffer alterations, since their biological clock is not respected and the basic gregarious human need is not appropriately fulfilled. Some measures should be taken in order to minimize these consequences.

It should not be forgotten that the body denounces when health is failing - whether by posture, physiognomy, whispering, gestures, looks and speeches. Likewise, the body expresses our feelings (happiness, sadness, hate, love, tenderness, respect, loving, sorrow, contempt and others). Our body is a machine and it is part of the human existence. Thus, we only exist because we have a body and because it is a reason for us to live.

\section{CONCLUSION}

This research has revealed that, despite the reduced number of employees, lack of supplies, professional devaluation, tiredness and stress, these employees enjoy working at the ITU and are concerned about providing assistance with quality and humanization. Therefore, it can be concluded that being a nursing professional working at the ITU means to face the challenge of acting

\section{REFERENCES}

1. Cardoso PR. Humanização em Terapia Intensiva: um estudo compreensivo com os profissionais que assistem crianças [dissertação]. Belo Horizonte: Escola de Enfermagem da Universidade Federal de Minas Gerais; 2001.

2. Pupulim JSL, Sawada NO. O cuidado de enfermagem e a invasão da privacidade do doente: uma questão ético-moral. Rev Latinoam Enferm. 2002; 10(3):433-8.

3. Lemos RCA, Rossi LA. O significado cultural atribuído ao centro de terapia intensiva por clientes e seus familiares: um elo entre a beira do abismo e a liberdade. Rev Latinoam Enferm. 2002; 10(3):345-57.

4. Lima RC, Brêtas JRS. Estudo comparativo entre séries de graduação em enfermagem: representações dos cuidados ao corpo do cliente. Acta Paul Enferm. 2006; 19(4): 37986.

5. Espósito VHC. Construindo o conhecimento da criança adulto: uma perspectiva interdisciplinar? São Paulo: Martinari; 2006.

6. Moreira RM, Padilha KG. Ocorrências iatrogênicas com in stressful conditions, but it is not a gratifying task.

It is possible that the stress related to the task overload and lack of supplies reported by the nursing professionals are responsible for the professional dissatisfaction feeling These findings incite us to reflect about the conditions in which the activity is performed and to what extent they may be contributing to their stress.

Therefore, solutions to change this reality are required and it is fundamental that the prevention and stress treatment are tackled as problems in this sector.

We also point out the direction commitment to optimize the working conditions, aiming at promoting worker health, as a concrete attitude to value them. Consequently, it raises the quality in the services at the intensive therapy units.

Even with these hardships, when providing humanized and quality care, the professionals are noticing that health care goes beyond the development of technical activities, involving feelings of dedication and care towards the other.

This paper concludes that being a nursing professional in an ITU means to face the challenge of working in stressful conditions without appraisal. However, the occupation can often be gratifying.

pacientes submetidos à ventilação mecânica em Unidade de Terapia Intensiva. Acta Paul Enferm. 2001; 14(2): 9-18.

7. Silva LD. Indicadores de qualidade do cuidado de enfermagem. Rev Enferm UERJ. 2003; 11(1): 111-6.

8. Hoga LAK. Causas de estresse e mecanismos de produção do bem-estar dos profissionais de enfermagem de unidade neonatal. Acta Paul Enferm. 2002; 15(2): 19-25.

9. Ferrareze MVG, Ferreira V, Carvalho AMP. Percepção do estresse entre enfermeiros que atuam em terapia intensiva. Acta Paul Enferm. 2006; 19(3) 310-5.

10. Bianchi ERF. Stress entre enfermeiros hospitalares. (Tese Livre Docência). São Paulo: Escola de Enfermagem da Universidade de São Paulo; 1999.

11. Atkinson LD. Fundamentos de enfermagem: introdução ao processo de enfermagem. Rio de Janeiro: Guanabara Koogan; 1994.

12. Rutenfranz J, Knauth P, Fischer FM. Trabalho em turnos e noturno. São Paulo: Hucitec; 1989.

13. Pires D. Reestruturação produtiva e trabalho em saúde no Brasil. São Paulo: Annablume; 1998. 